\title{
Monitoring and remediation technologies of organochlorine pesticides in drainage water
}

\author{
Ahmed Ismail $^{1}$, Aly Derbalah ${ }^{* 1}$, Sabry Shaheen ${ }^{2}$ \\ ${ }^{1}$ Kafr El-Sheikh University, Pesticides Chemistry and Toxicology Department, Faculty of Agriculture, 33516, Kafr \\ El-Sheikh, Egypt \\ ${ }^{2}$ Kafr El-Sheikh University, Soil Department, Faculty of Agriculture, 33516, Kafr El-Sheikh, Egypt \\ "Corresponding author: e-mail: aliderbalah@yahoo.com
}

\begin{abstract}
This study was carried out to monitor the presence of organochlorine in drainage water in Kafr-El-Sheikh Governorate, Egypt. Furthermore, to evaluate the efficiencies of different remediation techniques (advanced oxidation processes [AOPs] and bioremediation) for removing the most frequently detected compound (lindane) in drainage water. The results showed the presence of several organochlorine pesticides in all sampling sites. Lindane was detected with high frequency relative to other detected organochlorine in drainage water. Nano photo-Fenton like reagent was the most effective treatment for lindane removal in drainage water. Bioremediation of lindane by effective microorganisms (EMs) removed $100 \%$ of the lindane initial concentration. There is no remaining toxicity in lindane contaminated-water after remediation on treated rats relative to control with respect to histopathological changes in liver and kidney. Advanced oxidation processes especially with nanomaterials and bioremediation using effective microorganisms can be regarded as safe and effective remediation technologies of lindane in water.
\end{abstract}

Keywords: lindane, remediation, toxicity, degradation, water.

\section{INTRODUCTION}

One class of organic pollutants which has rightly gained greater attention in environmental studies is the organochlorine pesticides (OCPs). They are highly persistent and toxic in nature, and one of them, dieldrin, has been suspected to be carcinogenic ${ }^{1}$. Due to their persistence in the environment and biological accumulation through the food chain, OCPs can cause environmental damage and affect human health ${ }^{2-3}$. Moreover, due to the limits of water resources in Egypt and the sharp increase of human population, the re-use of drainage water for some purposes (agriculture irrigation and some industrial activities) considered a source of a major concern. However, the re-use of wastewater in agriculture purposes have a great risk on human health in Egypt. Therefore, monitoring of organic pollutants in drainage water and searching for effective remediation technologies to remove these pollutants are in demand to improve the water quality.

Advanced oxidation processes (AOPs), which are constituted by the combination of several oxidants, are characterized by the generation of very reactive and oxidizing free radicals in aqueous solution such as hydroxyl radicals, which posses a great destruction power ${ }^{4-7}$.

Bioremediation considered one of the most environmentally-sound and cost-effective methods for the decontamination and detoxification of pesticides different environmental compartments ${ }^{8}$. The technology of Effective Microorganisms (EMs) was developed during the 1970's at the University of Ryukyus, Okinawa, Japan?. Studies have suggested that EMs may have a number of applications, including agriculture, livestock, gardening and landscaping, composting, bioremediation, cleaning septic tanks, algal control and household uses ${ }^{\mathbf{1 0}}$.

However after remediation of pesticide residues in water, toxicity assessment is needed to directly assess the potential hazard of both original pollutants and its metabolites? ${ }^{7}$.

In this study the presence of organochlorine pesticides in drainage water in Kafr El-Sheikh governorate was monitored. The efficiency of advanced oxidation processes with different nano materials and bioremediation with effective microorganisms (EMs) were evaluated to achieve the total degradation of lindane. The histological changes in liver and kidney of rats treated with remediate water relative control were investigated to confirm the complete detoxification of lindane-contaminated water after remediation.

\section{EXPERIMENTAL}

\section{Chemicals}

Organochlroine mixture standard (aldrin, dieldrin, endosulfan, endrin, heptachlor, heptachlor epoxide, lindane, dichlorodiphenyltrichloroethane (DDT), Dichlorodiphenyldichloroethylene (DDE), and dichlorodiphenyldichloroethane (DDD) was obtained from Chem. Service, Inc 660,USA. Lindane with purity of $99.5 \%$ was obtained from Central laboratory for Pesticides, Agriculture Research Centre, Giza, Egypt. Zinc oxide (99.99\%) and ferric oxide $(99.9 \%)$ nanoparticles were obtained from Egypt Nanotech Company Limited, El-Wahat road, $6^{\text {th }}$ October, Cairo, Egypt. The zinc and ferric oxides particles size are 50 and $40 \mathrm{~nm}$, respectively with a surface area of 60 and $80 \mathrm{~m}^{2} / \mathrm{g}$, respectively. Hexane and methanol analytical grade solvents were obtained from Sigma Aldrich Company from Chemicals, U|SA. Hydrogen peroxide and ferric chloride El-Gomhoria Company for Chemical and Glasses, Cairo, Egypt.

Monitoring of the organochlorine compounds in drainage water

\section{Sampling sites}

Kafr El-Sheikh (Kotshinar Drainage), Fowa (Fowa Drainage No.11), Metobess (El-Hokss Drainage), Beila (Karakat Drainage), Balteem (Hafeer Shihabeldeen Drainage), Nashart Drainage and El-Hamoul (El-Hamoul Drainage) were selected to be the sampling sites to 
cover Kafr El-Sheikh Governorate drainage water areas. These sampling sites were selected according to their proximity to residential areas and agricultural activities. Amber glass bottles were used for sampling and were cleaned by detergent, putted in acid bath, sterilized in the oven and solvent-washed by acetone and hexane before using. Three-liter water samples were collected twice (in the spring and summer) from sampling sites. Glass bottles rinsed twice with the sample water prior to filling and closing. Sampling of water was carried out from the body of running water; the mouth of the bottle was pointed upstream and hands downstream to avoid contamination. The samples were collected for five days during each season. Water samples were acidified with know amount of 1 molar hydrochloric acid to inhibit the biological activity of the possible excite microorganisms. All samples clearly labeled by site number and sampling date. Three replicates were collected from each sampling site and all samples were transferred to the laboratory in ice container for further treatments.

\section{Extraction procedure}

Water samples $(500 \mathrm{ml})$ were extracted twice with 100 ml n-hexane each time. The extracts were combined and filtered through nylon 66 filter $(47 \mathrm{~mm} \times 0.45 \mu \mathrm{m}$, Supelco, USA). The filtrate was concentrated by rotary evaporation at $50^{\circ} \mathrm{C}$ to a volume of about $1 \mathrm{~mL}$. For clean up the concentrate was then transferred directly to an activated florisil column, and the OCP fractions were eluted with a mixture of diethyl ether/n-hexane (5:95) at a flow rate of $5 \mathrm{~mL} / \mathrm{min}$. Finally, the eluate was concentrated again by rotary evaporation and the final volume of the concentrate was made up to $1.0 \mathrm{~mL}$ volume by hexane for the GC-MS analysis ${ }^{11}$. Each sample was extracted and cleaned up three times.

\section{Gas Chromatography - Mass Spectrometry Analysis}

Helium (purity 99.99\%) was used as a carrier gas at

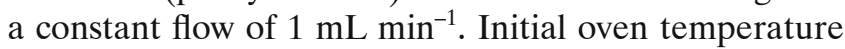
was set at $100^{\circ} \mathrm{C}$ for $2 \mathrm{~min}$, followed by a linear ramp to $180^{\circ} \mathrm{C}$ at a rate of $5^{\circ} \mathrm{C} \mathrm{min}^{-1}$ (hold for $2 \mathrm{~min}$ ). Subsequently, the temperature was raised to $200^{\circ} \mathrm{C}$ at a rate of $1.5^{\circ} \mathrm{C} \mathrm{min}-1$ followed by a ramp to 250 at a rate of $20^{\circ} \mathrm{C} \mathrm{min}^{-1}$. A final ramp to $280^{\circ} \mathrm{C}$ was performed at a rate of $30^{\circ} \mathrm{C}$ and a hold time of $7 \mathrm{~min}$. A split-spitless injector set at $250^{\circ} \mathrm{C}$ was always used and injections of $1 \mu \mathrm{L}$ were performed in the splitless mode. Transfer line temperature was set at $285^{\circ} \mathrm{C}$ and the source temperature at $220^{\circ} \mathrm{C}$. The mass spectrometer was operated in the electron impact mode (EI). Electron multiplier voltage was set at $1700 \mathrm{~V}$ and the dwell time at $25 \mathrm{~ms}^{\mathbf{1 2}}$. The three replicates of each sample were injected to calculate the mean concentration.

\section{Recovery evaluation}

The efficacy of the analytical steps was evaluated by fortifying distilled water samples with the mixture standard of organochlorine pesticides at concentration level of $1 \mathrm{mg} \mathrm{L}^{-1}$ and then the analytical steps (extraction, cleaning up and determination) that mentioned were performed and replicated three times. Good recovery range (90.8-98.6\%) of the tested pesticides was obtained (data not published).

\section{Photochemical remediation}

The scope of the experiments included the following treatments: Nano photo-Fenton-like reagent $\left[\mathrm{Fe}_{2} \mathrm{O}_{3}\right.$ (nano) $\left./ \mathrm{H}_{2} \mathrm{O}_{2} / \mathrm{UV}\right]$, nano photo zinc oxide combined with hydrogen peroxide [ $\mathrm{ZnO}$ (nano) $\left./ \mathrm{H}_{2} \mathrm{O}_{2} / \mathrm{UV}\right]$, photo Fenton like reagent $\left(\mathrm{Fe}^{3+} / \mathrm{H}_{2} \mathrm{O}_{2} / \mathrm{UV}\right)$, and photo zinc oxide combined with hydrogen peroxide $\left(\mathrm{ZnO} / \mathrm{H}_{2} \mathrm{O}_{2} /\right.$ UV). For the photo-Fenton-like reagent, a UV mercury lamp model VL-4.LC with a wavelength range of 254 to $365 \mathrm{~nm}$ was used for the irradiation of lindane in the aqueous solution. Ferric chloride and ferric oxide nanoparticles were used as sources of the iron catalyst. The solution was prepared by adding a desired amount of lindane $(5 \mathrm{mg} / \mathrm{L})$ to filtered El-Hokess drainage (i.e., the highly contaminated site with organochlorine compounds) and carefully agitating the solution. Then, freshly prepared ferric chloride or ferric oxide nanoparticles at a concentration of $50 \mathrm{mg} / \mathrm{L}$ as $\mathrm{Fe}^{3+}$ were added followed by the addition of $\mathrm{H}_{2} \mathrm{O}_{2}$ at a concentration of $0.05 \%$. After that, the solution was completed with water up to $1000 \mathrm{~mL}$. The initial $\mathrm{pH}$ of the solution was adjusted to 2.8 by using hydrochloric acid $1 \mathrm{M}$ for all experiments ${ }^{5}$. The solution was transferred from the standard flask to a quartz glass cell $(1000 \mathrm{~mL})$ and exposed to irradiation of the UV lamp under a constant temperature of $25^{\circ} \mathrm{C}$ with steering. The solutions $(100 \mu \mathrm{L})$ from the irradiated samples were removed at regular intervals (i.e., 10, 20, 40, 80, 160 and $320 \mathrm{~min}$ ) for high-performance liquid chromatography (HPLC) analysis.

For the $\mathrm{ZnO}$ catalyst, $5 \mathrm{mg} / \mathrm{L}$ of lindane, with the appropriate amount of $\mathrm{ZnO}$ or $\mathrm{ZnO}$ nanoparticles (300 mg/L), was shacked carefully before illumination followed by the addition of $\mathrm{H}_{2} \mathrm{O}_{2}$ at a concentration of $0.05 \%$. Then, the $\mathrm{pH}$ was adjusted to 7 , which was the optimum $\mathrm{pH}$ for the $\mathrm{ZnO}$ catalyst (Derbalah 2009). The suspension was kept in the dark for $30 \mathrm{~min}$ before illumination to achieve maximum adsorption of the pesticide onto the semiconductor surface ${ }^{7}$. The solutions from the irradiated samples were removed at regular intervals for HPLC analysis as mentioned before elsewhere. Each experiment was replicated three times for accurate data. Blank experiments were carried out with the tested insecticide alone under the optimum $\mathrm{pH}$ and dark conditions were run in parallel at all intervals to assess biotic loss of lindane. The data was negligible due to the high persistence of lindane and the short time.

\section{HPLC analysis}

The irradiated samples were analyzed directly by HPLC (1100 series; Agilent Technologies, Palo Alto, California). The HPLC column used (i.d. of $4.6 \mathrm{~mm}$; length of 250 $\mathrm{mm}$ ) was filled with Wakosil-II 5 C18-100 (Wako Pure Chemical Industries, Ltd., Osaka, Japan). A mixture of methanol and distilled water (30:70) was used as mobile phase under the isocratic elution mode. The flow rate was maintained at $1 \mathrm{~mL} / \mathrm{min}$ and the $\mathrm{UV}$ detector wavelength was adjusted to be $202 \mathrm{~nm}^{\mathbf{1 3}}$.

\section{Bioremediation technique}

The effective microorganisms formulation (EMs1) used for bioremediation of lindane was obtained from the Egyptian Ministry of Agriculture, Giza, Egypt. This formulation contains 60 species of beneficial microorganisms 
grown in special media and produced in Egypt under supervision of the Japanese EMRO Scientific Organization (Okinawa, Japan). Enrichment and propagation were carried out in sterilized 250-mL Erlenmeyer flasks using $190 \mathrm{~mL}$ mineral salt medium (MSM)[14] and $10 \mathrm{~mL}$ of effective microorganisms (5 $\mathrm{mL}$ from the formulation) supplemented with lindane at a concentration of $5 \mathrm{mg} / \mathrm{L}$. The cultures were incubated at $30^{\circ} \mathrm{C}, \mathrm{pH} 7$ and 150 $\mathrm{rpm}$ as optimum conditions for the growth of the tested effective microorganisms ${ }^{15}$. Samples were collected at 0 , $3,8,11,15,19$, and 23 days for monitoring the degradation of the tested insecticide. Control flasks of equal volumes of mineral salt liquid (MSL) medium and the tested insecticide without the effective microorganisms were run in parallel at all intervals to assess biotic loss. The collected water samples of the tested insecticide were filtered using syringe filter $(0.2 \mathrm{~mm})^{15}$ followed by HPLC analysis as mentioned before. Each experiment was replicated three times for accurate data.

\section{Toxicity test}

To confirm the complete detoxification of lindane in treated water, toxicity test was conducted on rats. Lindane contaminated-waters after treatment with $\mathrm{Fe}^{3+} /$ $\mathrm{H}_{2} \mathrm{O}_{2} / \mathrm{UV}, \mathrm{Fe}_{2} \mathrm{O}_{3}$ (nano) $/ \mathrm{H}_{2} \mathrm{O}_{2} / \mathrm{UV}, \mathrm{ZnO} / \mathrm{H}_{2} \mathrm{O}_{2} / \mathrm{UV}, \mathrm{ZnO}$ (nano) $/ \mathrm{H}_{2} \mathrm{O}_{2} / \mathrm{UV}$ and EMs were orally administrated to the tested rats. This test was carried out to measure the effect of the possible remaining lindane (parent or metabolites) in the water samples after remediation on rats with respect to histological changes in liver and kidney relative to control.

Adult rats (Sprague dauley) with 100-120 g of weight, obtained from Faculty of Veterinary Medicine, Kafr-El-Sheikh University were used. Rats were housed in polypropylene cages under standard conditions with free access to drinking water and food. The animals were randomly divided into five groups, each comprising of three animals and water samples (possibly contain lindane or its toxic metabolite) after remediation by different treatments were given to rats as oral administration. Water samples were adjusted to neutral $\mathrm{pH}$, filtered and was free of hydrogen peroxide before orally administrated to rats. Control group rats was fed with normal diet and given oral dose containing no lindane. After 21 days, the rats were scarified under anesthesia and the kidney and liver organs were removed and prepared for histopathological examination according to the method described by Bancroft and Stevens ${ }^{\mathbf{1 6}}$. The histopathology test was carried out at Department of Histopathology, Faculty of Veterinary Medicine, Cairo University Egypt.

\section{RESULTS AND DISCUSSION}

\section{Monitoring of organochlorine pesticides in drainage water}

The analytical parameters of organochlrine pesticides and maximum residue limits of these pesticides are shown in Table (1). The results of wastewater analysis from different sampling sites in Kafr El-sheikh governorate showed the presence of several organochlorine pesticide residues (aldrin, dieldrin, endosulfan, endrin, heptachlor, heptachlor epoxide, lindane, p, p-DDT, p, p-DDE and DDD) in the two sampling times (Tables 2-3). The concentrations of organochlorine pesticides ranged from 0.01 to $0.980 \mu \mathrm{g} \mathrm{L}^{-1}$ in drainage water at all sampling sites. With the concerning the sampling sites, the results showed that El-Hokss drainage was the highest contaminated site with organochlorine pesticides while Fowa drainage no. 11 was the lowest contaminated one. With the respect to the detection frequency, lindane was the

Table 1. Analytical method parameters of OCPs by the proposed method

\begin{tabular}{|l|c|c|c|}
\hline Compound name & $\begin{array}{c}\text { Limit of detection } \\
{[\mathrm{ng} / \mathrm{L}]}\end{array}$ & $\begin{array}{c}\text { Limit of quantification } \\
{[\mathrm{ng} / \mathrm{L}]}\end{array}$ & Correlation coefficients $\left[\mathrm{R}^{2}\right]$ \\
\hline Lindane & 5.0 & 20 & 0.992 \\
\hline Heptachlor & 4.0 & 20 & 0.995 \\
\hline Aldrin & 6.0 & 40 & 0.998 \\
\hline Hept. epoxide & 15 & 50 & 0.994 \\
\hline Endosulfan & 14 & 45 & 0.998 \\
\hline p.p-DDE & 10 & 75 & 0.997 \\
\hline Dieldrin & 7.0 & 25 & 0.983 \\
\hline Endrin & 15 & 100 & 0.996 \\
\hline DDD & 20 & 60 & 0.999 \\
\hline p.p-DDT & 8.0 & 20 & 0.990 \\
\hline
\end{tabular}

Table 2. Mean concentration of detected organochlorine pesticides $\left(\mu \mathrm{g} \mathrm{L}{ }^{-1}\right)$ at all sampling sites in spring season

\begin{tabular}{|l|c|c|c|c|c|c|c|c|}
\hline Compounds & $\begin{array}{c}\text { Fowa Drainge } \\
\text { No.11 }\end{array}$ & $\begin{array}{c}\text { El-Hokss } \\
\text { Drainage }\end{array}$ & $\begin{array}{c}\text { Karakat } \\
\text { Drainage }\end{array}$ & $\begin{array}{c}\text { Hafeer shihab } \\
\text { eldeen Drainage }\end{array}$ & $\begin{array}{c}\text { Nashart } \\
\text { Drainage }\end{array}$ & $\begin{array}{c}\text { El-Hamoul } \\
\text { Drainage }\end{array}$ & $\begin{array}{c}\text { Kotshinar } \\
\text { Drainage } \\
{[\mathrm{Kfs}]}\end{array}$ & $\begin{array}{c}\text { Maximum Residue } \\
\text { limits }[\mu \mathrm{L} / \mathrm{L}]\end{array}$ \\
\hline Lindane & $0.49 \pm 0.05$ & $0.98 \pm 0.1$ & $0.17 \pm 0.01$ & $0.20 \pm 0.02$ & $0.95 \pm 0.08$ & $0.88 \pm 0.08$ & $0.58 \pm 0.05$ & 10 \\
\hline Heptachlor & $0.19 \pm 0.01$ & $0.86 \pm 0.07$ & $0.58 \pm 0.04$ & N.D. & $0.53 \pm 0.05$ & N.D. & $0.91 \pm 0.08$ & 10 \\
\hline Aldrin & $0.24 \pm 0.02$ & $0.96 \pm 0.09$ & N.D. & $0.88 \pm 0.07$ & N.D. & N.D. & N.D. & 4.0 \\
\hline $\begin{array}{l}\text { Hept. } \\
\text { epoxide }\end{array}$ & N.D. & $0.97 \pm 0.09$ & $0.05 \pm 0.01$ & $0.15 \pm 0.01$ & N.D. & $0.12 \pm 0.01$ & $0.24 \pm 0.02$ & 10 \\
\hline Endosulfan & N.D. & N.D. & N.D. & $0.26 \pm 0.02$ & N.D. & $0.31 \pm 0.03$ & $0.18 \pm 0.01$ & 20 \\
\hline p.p-DDE & N.D. & N.D. & N.D. & N.D. & N.D. & N.D. & N.D. & 1.0 \\
\hline Dieldrin & $0.51 \pm 0.04$ & $0.33 \pm 0.03$ & N.D. & $0.18 \pm 0.01$ & $0.14 \pm 0.01$ & N.D. & N.D. & 4.0 \\
\hline Endrin & N.D. & $0.88 \pm 0.08$ & $0.68 \pm 0.05$ & $0.65 \pm 0.05$ & $0.23 \pm 0.02$ & $0.25 \pm 0.02$ & $0.27 \pm 0.02$ & 2.0 \\
\hline DDD & N.D. & $0.77 \pm 0.06$ & N.D. & N.D. & $0.19 \pm 0.01$ & N.D. & ND & 1.0 \\
\hline p.p-DDT & $0.43 \pm 0.03$ & $0.33 \pm 0.02$ & $0.06 \pm 0.01$ & N.D. & N.D. & $0.31 \pm 0.03$ & $0.15 \pm 0.01$ & 1.0 \\
\hline
\end{tabular}


Table 3. Mean concentration of detected pesticide residues $\left(\mu \mathrm{g} \mathrm{L}^{-1}\right)$ at all sampling sites in summer season

\begin{tabular}{|l|c|c|c|c|c|c|c|c|}
\hline Compounds & $\begin{array}{c}\text { Fowa Drainge } \\
\text { No. } 11\end{array}$ & $\begin{array}{c}\text { El-Hokss } \\
\text { Drainage }\end{array}$ & $\begin{array}{c}\text { Karakat } \\
\text { Drainage }\end{array}$ & $\begin{array}{c}\text { Hafeer shihab } \\
\text { eldeen Drainage }\end{array}$ & $\begin{array}{c}\text { Nashart } \\
\text { Drainage }\end{array}$ & $\begin{array}{c}\text { El-Hamoul } \\
\text { Drainage }\end{array}$ & $\begin{array}{c}\text { Kotshinar } \\
\text { Drainage } \\
{[\mathrm{Kfs}]}\end{array}$ & $\begin{array}{c}\text { Maximum } \\
\text { Residue limits } \\
{[\mu \mathrm{L} / \mathrm{L}]}\end{array}$ \\
\hline Lindane & $0.29 \pm 0.02$ & $0.86 \pm 0.08$ & $0.72 \pm 0.07$ & $0.48 \pm 0.04$ & $0.43 \pm 0.04$ & $0.80 \pm 0.08$ & $0.76 \pm 0.07$ & 10 \\
\hline Heptachlor & N.D. & $0.03 \pm 0.001$ & $0.02 \pm 0.001$ & N.D. & N.D. & N.D. & N.D. & 10 \\
\hline Aldrin & $0.05 \pm 0.001$ & $0.27 \pm 0.02$ & N.D. & $0.14 \pm 0.01$ & $0.05 \pm 0.005$ & $0.05 \pm 0.001$ & $0.07 \pm 0.001$ & 4.0 \\
\hline $\begin{array}{l}\text { Hept. } \\
\text { epoxide }\end{array}$ & $0.56 \pm 0.05$ & $0.24 \pm 0.02$ & N.D. & N.D. & $0.22 \pm 0.02$ & $0.25 \pm 0.02$ & $0.08 \pm 0.008$ & 10 \\
\hline Endosulfan & N.D. & $0.06 \pm 0.001$ & $0.05 \pm 0.001$ & $0.34 \pm 0.03$ & $0.49 \pm 0.04$ & $0.20 \pm 0.02$ & ND & 20 \\
\hline p.p-DDE & N.D. & $0.09 \pm 0.001$ & $0.48 \pm 0.04$ & N.D. & N.D. & N.D. & $0.28 \pm 0.02$ & 1.0 \\
\hline Dieldrin & N.D. & $0.01 \pm 0.001$ & $0.01 \pm 0.001$ & N.D. & N.D. & N.D. & N.D. & 4.0 \\
\hline Endrin & N.D. & $0.05 \pm 0.005$ & N.D. & $0.75 \pm 0.07$ & $0.20 \pm 0.02$ & $0.54 \pm 0.05$ & $0.56 \pm 0.05$ & 2.0 \\
\hline DDD & N.D. & $0.41 \pm 0.04$ & $0.08 \pm 0.008$ & N.D. & $0.39 \pm 0.03$ & $0.07 \pm 0.001$ & N.D. & 1.0 \\
\hline p.p-DDT & $0.05 \pm 0.001$ & $0.02 \pm 0.002$ & N.D. & $0.01 \pm 0.001$ & N.D. & N.D. & $0.05 \pm 0.001$ & 1.0 \\
\hline
\end{tabular}

highly detected compounds while DDD was the lowest detected one in all sampling sites. The detection frequency and concentration level of the detected pesticides were higher in spring relative to summer season.

The results of pesticides monitoring showed the presence of several organochlorine compounds in drainage water and this are in agreement with those reported by Abd-Allah and Hesham ${ }^{17}$ and Ashry et al. ${ }^{18}$. Spite of some pesticides still present in wastewater after treatment, their concentration level was lower than the maximum residue limits (MRLs) according to Egyptian water quality Standards (Tables 2-3). It is important to note that most of these organochlorines were virtually phased out many years ago and their presence in water residues were from past applications. Firstly, this is attributable to the persistent nature of these compounds. Secondly, water from the Nile originates from the African plateau and crosses eight countries before reaching Egyptian territory (e.g., Sudan, Ethiopia, Uganda, Tanzania, Kenya, Zaire, Rwanda and Burundi). While flowing through these countries, the Nile River is loaded with various types of pesticides and many other contaminants. Thus, it arrives in Egypt after already being contaminated with different pollutants, including the persistent chlorinated pesticides ${ }^{19}$. Thirdly, combustion of domestic wastes is a potential source of PTS in the Egyptian environment with a decreasing abundance in the order PAHs $>$ PCBs $>$ DDTs $>\mathrm{HCBs}>$ chlordane $>\mathrm{HCHs}>$ endosulfan ${ }^{20}$. Fourthly, Nile River flowing through Kafr El-Zayat City which contained one of the largest pesticides factory in Egypt that flows his drainage contaminated water to Nile water, therefore, the Nile River is loaded with various types of pesticides before reaching Kafr-El-Sheikh Governorate $^{20}$. In addition, organochlorines still have limited use in Egypt as a rodenticide and termiticide ${ }^{20}$.

Finally, the misuse of these pesticides by concerned individuals in addition to the lack of or weak national control is behind the presence of these pesticides in water ${ }^{18}$. The occurrence of such pesticide residues in wastewater represents an environmental and health hazard due to the re-use in agriculture purposes. Frequent monitoring program had urgently needed in order to assess health risks associated with such contaminates especially with chronic exposure or a life-long intake of contaminated drinking water.

\section{Degradation of lindane by advanced oxidation processes}

The first parameter considered in this study was the losses in lindane concentration with the irradiation time.
The results in Figure 1 showed that, the irradiation under $\mathrm{Fe}_{2} \mathrm{O}_{3}$ (nano) $/ \mathrm{H}_{2} \mathrm{O}_{2} / \mathrm{UV}$ system gave the highest degradation rate of lindane followed by $\mathrm{ZnO}$ (nano) $/ \mathrm{H}_{2} \mathrm{O}_{2} /$ $\mathrm{UV}, \mathrm{Fe}^{3+} / \mathrm{H}_{2} \mathrm{O}_{2} / \mathrm{UV}$ and $\mathrm{ZnO} / \mathrm{H}_{2} \mathrm{O}_{2} / \mathrm{UV}$ systems, respectively. A complete degradation of lindane $(100 \%)$ was achieved under $\mathrm{Fe}_{2} \mathrm{O}_{3}$ (nano) $/ \mathrm{H}_{2} \mathrm{O}_{2} / \mathrm{UV}$ system followed $\mathrm{ZnO}$ (nano) $/ \mathrm{H}_{2} \mathrm{O}_{2} / \mathrm{UV}$ (98\%), $\mathrm{Fe}^{3+} / \mathrm{H}_{2} \mathrm{O}_{2} / \mathrm{UV}$ (96.8\%) and $\mathrm{ZnO} / \mathrm{H}_{2} \mathrm{O}_{2} / \mathrm{UV}(95.2 \%)$ systems within $320 \mathrm{~min}$ of irradiation time, respectively (Fig. 1).

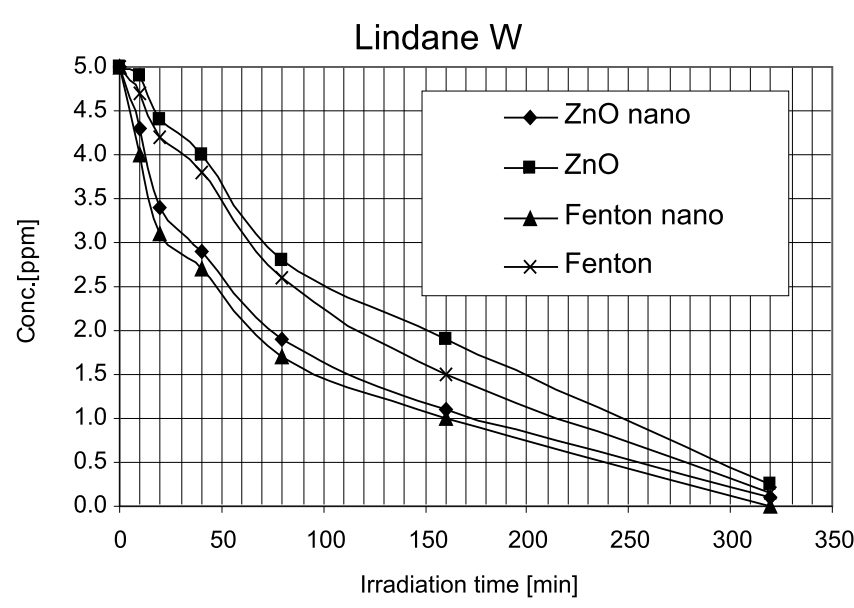

Figure 1. Degradation of lindane at initial concentration of $5 \mathrm{mg} / \mathrm{L}$ in wastewater $\mathrm{Fe}_{2} \mathrm{O}_{3}$ (nano) $/ \mathrm{H}_{2} \mathrm{O}_{2} / \mathrm{UV}, \mathrm{Fe}^{+3} /$ $\mathrm{H}_{2} \mathrm{O}_{2} / \mathrm{UV}, \mathrm{ZnO}$ (nano) $/ \mathrm{H}_{2} \mathrm{O}_{2} / \mathrm{UV}$ and $\mathrm{ZnO} / \mathrm{H}_{2} \mathrm{O}_{2} / \mathrm{UV}$ systems

The results showed that, the degradation rate of lindane was enhanced by irradiation under $\mathrm{Fe}_{2} \mathrm{O}_{3}$ (nano)/ $\mathrm{H}_{2} \mathrm{O}_{2} / \mathrm{UV}$ and $\mathrm{ZnO}$ (nano) $/ \mathrm{H}_{2} \mathrm{O}_{2} / \mathrm{UV}$ systems relative to the degradation under other photochemical remediation systems. This enhancement in lindane degradation rate under $\mathrm{Fe}_{2} \mathrm{O}_{3}$ (nano) $/ \mathrm{H}_{2} \mathrm{O}_{2} / \mathrm{UV}$ and $\mathrm{ZnO}$ (nano) $/ \mathrm{H}_{2} \mathrm{O}_{2} / \mathrm{UV}$ systems compared to other photochemical irradiation systems may be due to the fact that the stabilized nanoparticles offer much greater surface area and reactivity which lead to higher generation rate of hydroxyl radicals relative to the bulk materials ${ }^{21-22}$.

After 100 min of irradiation time, the degradation rate of the remaining lindane was quite slower than the first 100 min under all photochemical remediation systems. This is might be due to the low remaining concentration of lindane (lower than 20\% of its initial concentration) after $100 \mathrm{~min}$ of irradiation time which lead to high delivery rate of $\mathrm{Fe}^{3+} / \mathrm{H}_{2} \mathrm{O}_{2}$ and $\mathrm{ZnO} / \mathrm{H}_{2} \mathrm{O}_{2}$ systems corresponds to higher concentrations of these reagents, and this subsequently increase their ability to 
compete with lindane as hydroxyl radical scavengers (eqs. $1,2)^{5,7,23-25}$. Also, chloride and carbonate ions naturally present in water react as hydroxyl radical scavengers ${ }^{26}$ as shown in equations 3 and 4 .

$$
\begin{aligned}
& \mathrm{Fe}^{2+}+\mathrm{OH} \rightarrow \mathrm{Fe}^{3+}++\mathrm{OH} \\
& \mathrm{OH}+\mathrm{H}_{2} \mathrm{O}_{2} \rightarrow \mathrm{HO}_{2}+\mathrm{H} 2 \mathrm{O} \\
& \mathrm{Cl}^{-}+\cdot \mathrm{OH} \rightarrow \mathrm{Cl}++\mathrm{OH}^{-} \\
& \mathrm{CO}_{3}^{-2}+\cdot \mathrm{OH} \rightarrow \mathrm{CO}_{3}^{-\cdot}+\mathrm{OH}^{-}
\end{aligned}
$$

The degradation rate of lindane under $\mathrm{Fe}_{2} \mathrm{O}_{3}$ (nano)/ $\mathrm{H}_{2} \mathrm{O}_{2} / \mathrm{UV}$ and $\mathrm{Fe}^{3+} / \mathrm{H}_{2} \mathrm{O}_{2} / \mathrm{UV}$ systems was higher than that under $\mathrm{ZnO}$ (nano) $/ \mathrm{H}_{2} \mathrm{O}_{2} / \mathrm{UV}$ and $\mathrm{ZnO} / \mathrm{H}_{2} \mathrm{O}_{2} / \mathrm{UV}$ systems. This is may be due to the high generation rate of hydroxyl radicals under photo Fenton like reagent (nano or normal) relative to photo zinc oxide combined with hydrogen peroxide (nano or normal) ${ }^{7}$.

The degradation rate of lindane under $\mathrm{ZnO}$ (nano)/ $\mathrm{H}_{2} \mathrm{O}_{2} / \mathrm{UV}$ system was higher than that under $\mathrm{ZnO} / \mathrm{H}_{2} \mathrm{O}_{2} /$ UV system and this is may be due to the effect of particle size of nano zinc oxide. The effect of particle size on the photodegradation efficiency can be ascribed to two reasons. 1) When the size of $\mathrm{ZnO}$ crystals decreases, the amount of the dispersion particles per volume in the solution will increase, resulting in the enhancement of the photon absorbance. 2) The surface area of $\mathrm{ZnO}$ photocatalyst will increase as the size of $\mathrm{ZnO}$ crystals decreases, which will promote the adsorption of more insecticide molecules on the surface ${ }^{27}$.

The degradation rate of lindane under $\mathrm{Fe}_{2} \mathrm{O}_{3}$ (nano)/ $\mathrm{H}_{2} \mathrm{O}_{2} / \mathrm{UV}$ system was higher than that under $\mathrm{Fe}^{3+} /$ $\mathrm{H}_{2} \mathrm{O}_{2} / \mathrm{UV}$ system and this is may be due to the effect of nano ferric oxide particle size which agree with ${ }^{\mathbf{2 8 - 2 9}}$ who developed a new catalyst using nanosize particles with a high surface area that can accelerate the photo Fenton-like reaction by increasing the hydroxyl radicals generation rate.

The ferric and zinc oxide nanocatalysts are very reactive because the active sites are located on the surface. As such, they have a low diffusional resistance, and are easily accessible to the substrate molecules. Nanocatalysis is but one of the many practical applications of nanotechnology which is concerned with the synthesis and functions of materials at the nanoscale range (lower than $100 \mathrm{~nm})^{30-32}$. An important feature of nanomaterials is that their surface properties can be very different from those shown by their macroscopic or bulk counterparts ${ }^{33}$. As the term suggests, 'nanocatalysis' uses nanoparticles and nanosize porous supports with controlled shapes and sizes ${ }^{\mathbf{3 4}}$. The application of nanoparticles as catalysts of the Fenton-like and photo-Fenton reactions has been described by several investigators ${ }^{\mathbf{2 8}, 29,35-37}$. In comparison with their microsize counterparts, nanoparticles show higher catalytic activities because of their large specific surface where catalytically active sites are exposed ${ }^{\mathbf{3 8}}$. The advantage of using nanoparticles as catalysts for Fenton-like reagent would more than offset the disadvantage (associated with the use of iron(III) catalysts) of requiring ultraviolet radiation to accelerate the reaction. Form all previous discussion, ferric oxide and zinc oxide nanoparticles are potentially useful for remediation of lindane polluted sites ${ }^{39}$.

\section{Biodegradation of Lindane using effective microorga- nisms (EMs)}

The degradation ability of the effective microorganisms to lindane was illustrated in Figure 2. The effective microorganisms showed high potential in the degradation of the tested insecticide. Nearly $99 \%$ of lindane initial concentration $(5 \mathrm{mg} / \mathrm{L})$ was degraded within three weeks of incubation with the effective microorganisms.

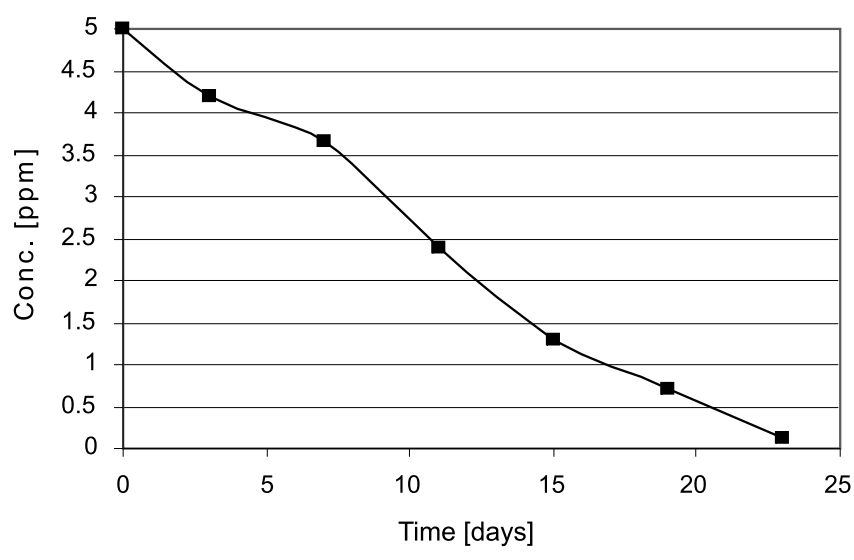

Figure 2. Biodegradation of lindane at initial concentration of $5 \mathrm{mg} / \mathrm{L}$ in wastewater by effective microorganisms (EMs)

With the concerning the bioremediation of lindane, effective microorganisms showed high degradation ability against lindane in drainage water. This is may be due to that the effective microorganisms is not one microorganism but a mixture of microorganisms ${ }^{40} \mathrm{It}$ is also described as a multi-culture of coexisting anaerobic and aerobic beneficial microorganisms ${ }^{\mathbf{4 1}}$. Therefore, its degradation ability to lindane may be faster and effective than using one microorganism. The main species involved in EMs include: lactic acid bacteria (Lactobacillus plantarum, Lactobacillus casei and Streptoccus lactis), photosynthetic bacteria (Rhodopseudomonas palustrus and Rhodobacter spaeroides) yeasts (Saccharomyces cerevisiae and Candida utilis), actinomycetes (Streptomyces albus, and Streptomyces griseus) and fermenting fungi (Aspergillus oryzae and Mucor hiemalis) ${ }^{\mathbf{4 2}}$.

As a conclusion, effective microorganisms could be used in various kinds of aerobic and anaerobic systems for treating agricultural wastes which represent the first point of discharge of many chemicals into environment. The effective and stable degradation capacity of this EMs technology in utilizing and degrading this compound reflected their efficacy in biotechnological application for the bioremediation of such contaminated water. These results indicated that EMs are more stable in retaining their ability to completely degrade lindane because these effective microorganisms live in symbiotic relationships and their influence on the lindane are sum of all activities of these microorganisms. Where the metabolites formed by one type of microorganism may be utilized by other group of microorganisms. This study so far suggested that microorganisms endowed with this property of degradation of toxic pollutants are a boon to mankind. Future studies on the genes responsible for enhanced biodegradation will enable us to elucidate the exact degradation pathway involved in its microbial biodegradation. 


\section{Toxicity assessment}

\section{The histopathological changes in the kidney}

The normal structure of kidney tissue is shown in Figure $3 \mathrm{~A}$. For the rats treated with lindane after remediation with $\mathrm{Fe}_{2} \mathrm{O}_{3}$ (nano) $/ \mathrm{H}_{2} \mathrm{O}_{2} / \mathrm{UV}$ (Fig. 3B), $\mathrm{Fe}^{3+} /$ $\mathrm{H}_{2} \mathrm{O}_{2} / \mathrm{UV}$ (Fig. 3C), $\mathrm{ZnO}$ (nano)/ $\mathrm{H}_{2} \mathrm{O}_{2} / \mathrm{UV}$ (Fig. 3D), $\mathrm{ZnO} / \mathrm{H}_{2} \mathrm{O}_{2} / \mathrm{UV}$ (Fig. 3E) and effective microorganisms (Fig. 3F), the tissues were normal like control (Fig. 3B) but for preiveascular oedema (Fig. 3C), small vaculations of epithelial lining renal tubules (Figs. 3D, E) as will as glomeular tults and epithelial lining renal tubules (Fig. 3F). To confirm the safety of materials used in the different remediation processes, some rats treated with $\mathrm{Fe}_{2} \mathrm{O}_{3}$ (nano) $/ \mathrm{H}_{2} \mathrm{O}_{2} / \mathrm{UV}$ (Fig. 3B), $\mathrm{Fe}^{3+} / \mathrm{H}_{2} \mathrm{O}_{2} / \mathrm{UV}$ (Fig. 3C), $\mathrm{ZnO}$ (nano) $/ \mathrm{H}_{2} \mathrm{O}_{2} / \mathrm{UV}$ (D), $\mathrm{ZnO} / \mathrm{H}_{2} \mathrm{O}_{2} / \mathrm{UV}$ (Fig. 3E) and effective microorganisms (Fig. 3F) without lindane and the kidney tissues were normal like control (data not published).

\section{The histopathological changes in the liver}

The normal structure of liver tissue is shown in Figure 4A. For the rats treated with lindane after remediation with $\mathrm{Fe}_{2} \mathrm{O}_{3}$ (nano) $/ \mathrm{H}_{2} \mathrm{O}_{2} / \mathrm{UV}$ (Fig. 4B), $\mathrm{Fe}^{3+} /$ $\mathrm{H}_{2} \mathrm{O}_{2} / \mathrm{UV}$ (Fig. 4C), $\mathrm{ZnO}$ (nano) $/ \mathrm{H}_{2} \mathrm{O}_{2} / \mathrm{UV}$ (Fig. 4D), $\mathrm{ZnO} / \mathrm{H}_{2} \mathrm{O}_{2} / \mathrm{UV}$ (Fig. 4E) and Effective microorganisms (Fig. 4F), the tissues were like control but for hydropic

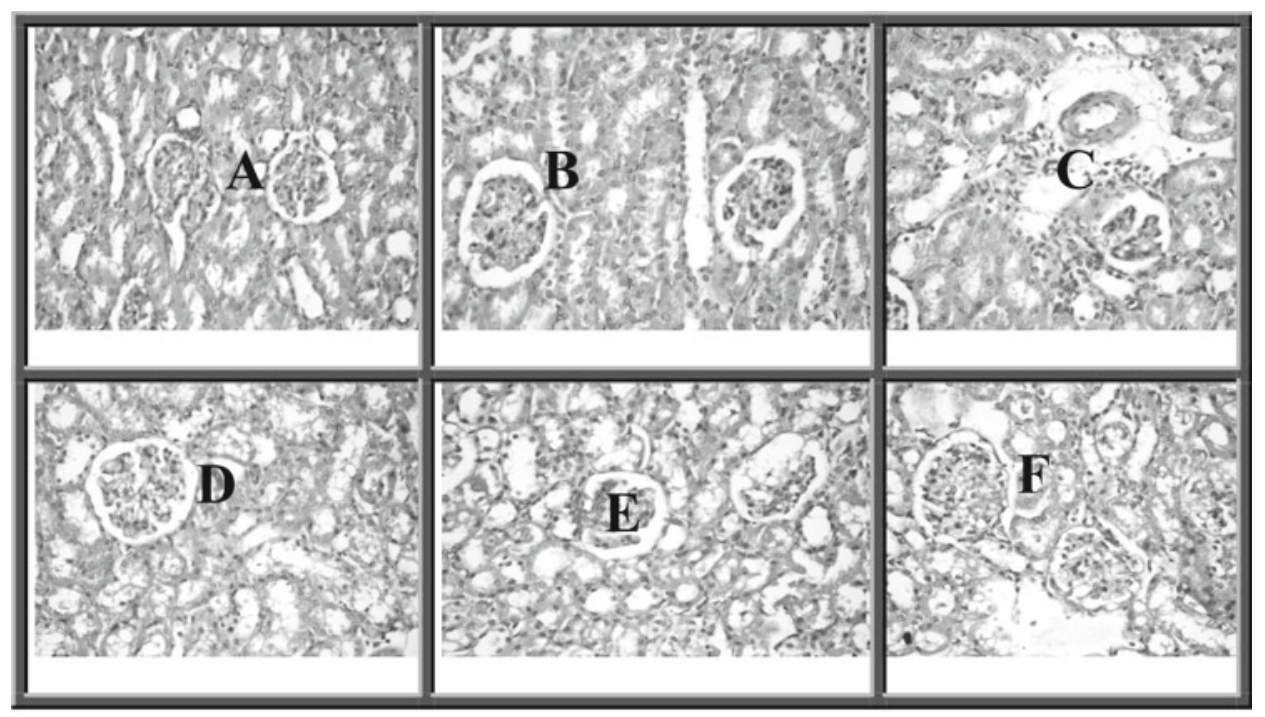

Figure 3. Sections in kidney of rats treated with lindane after remediation with $\mathrm{Fe}_{2} \mathrm{O}_{3}($ nano $) / \mathrm{H}_{2} \mathrm{O}_{2} / \mathrm{UV}^{(B)}, \mathrm{Fe}^{+3} / \mathrm{H}_{2} \mathrm{O}_{2} / \mathrm{UV}(\mathrm{C})$, $\mathrm{ZnO}$ (nano) $/ \mathrm{H}_{2} \mathrm{O}_{2} / \mathrm{UV}$ (D) and $\mathrm{ZnO} / \mathrm{H}_{2} \mathrm{O}_{2} / \mathrm{UV}$ (E) and Effective microorganisms (F) relative to control (A)

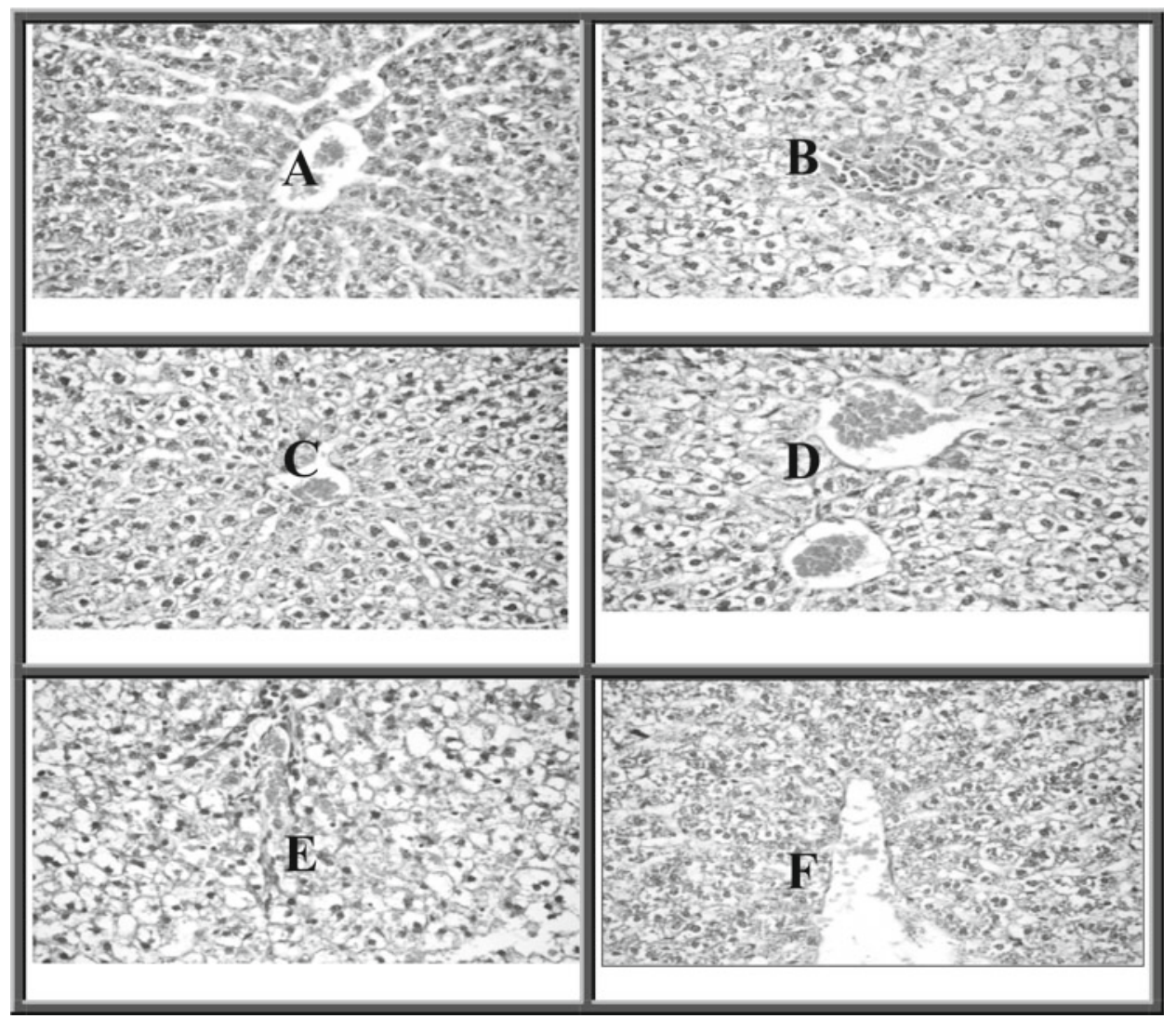

Figure 4. Sections in liver of rats treated with lindane after remediation with $\mathrm{Fe}_{2} \mathrm{O}_{3}(\mathrm{nano}) / \mathrm{H}_{2} \mathrm{O}_{2} / \mathrm{UV}(\mathrm{B}), \mathrm{Fe}^{+3} / \mathrm{H}_{2} \mathrm{O}_{2} / \mathrm{UV}(\mathrm{C}), \mathrm{ZnO}$ (nano) $/ \mathrm{H}_{2} \mathrm{O}_{2} / \mathrm{UV}$ (D) and $\mathrm{ZnO} / \mathrm{H}_{2} \mathrm{O}_{2} / \mathrm{UV}(\mathrm{E})$ and Effective microorganisms (F) relative to control (A) 
degeneration of hepatocytes (Figs. 4B, C, F), congestion of central vein and hydropic degeneration in hepatocytes (Fig. 4D) and congestion of hepatic sensoids as well as vacuolization of hepatocytes (Fig. 4E). To confirm the safety of materials used in the different remediation processes, some rats treated with $\mathrm{Fe}_{2} \mathrm{O}_{3}$ (nano) $/ \mathrm{H}_{2} \mathrm{O}_{2} / \mathrm{UV}$ (Fig. 4B), $\mathrm{Fe}^{3+} / \mathrm{H}_{2} \mathrm{O}_{2} / \mathrm{UV}$ (Fig. $4 \mathrm{C}$ ), $\mathrm{ZnO}$ (nano) $/ \mathrm{H}_{2} \mathrm{O}_{2} /$ UV (Fig. 4D), $\mathrm{ZnO} / \mathrm{H}_{2} \mathrm{O}_{2} / \mathrm{UV}$ (Fig. 4E) and effective microorganisms $(\mathrm{F})$ without lindane and liver tissues were normal like control (data not published).

To evaluate the efficacy of different tested remediation techniques in removing lindane from wastewater, toxicity assessment was carried out with respect to histology test. The histology test for all remediation techniques of lindane in wastewater showed no significant changes in kidney or liver of treated rats relative to control treatment. This is implies the complete detoxification of lindane and its possible toxic products in treated wastewater with different remediation techniques. Also, this is implying the safety of all tested chemical and biological remediation techniques on human health especially when we extend the remediation time.

In terms of the removal of used nonmaterials from water after treatment, these could be removed by the addition of natural colloids that make aggregation and sedimentation of these materials and remove them from water $^{43}$. In addition, membranes with suitable porous structures and homogeneous pore-size distribution can separate nanoparticles (NPs) that are less than $10 \mathrm{~nm}$ in size. Hence, ultrafiltration and nanofiltration membranes are ideal for separating NPs and large molecules such as proteins because their pore sizes range from 1 to $100 \mathrm{~nm}^{44}$. Regarding removal of effective microorganisms, this bioformulation is very safe and has multiple uses such as serving as growth promoters for humans and poultry as well as it used to improve soil fertility etc. Spite of its safety and benefits, it can be remove easy by passing treated water through nanofilter membrane. Since polymer ultra-filtration membranes have been used for the separation of various foods, biological, pharmaceutical systems as well as for water purification ${ }^{44}$.

This study relative to other previous studies used effective microorganisms' formulation for the first time in lindane biodegradation or bioremediation. This is considered a first step for using this safe and effective formulation in the field of wastewater treatment. Moreover, the histology technique to confirm the total detoxification of lindane in remediated water sound interest. Moreover, the toxicity of nanomaterials and effective microorganisms itself was evaluated with respect to histological change in kidney and liver relative to control (data not published) and this also reflect the need to evaluate the side effects or the safety of nanomaterials not only its efficacy.

\section{CONCULSIONS}

These results clearly indicate the presence of numerous organochlorine compounds in drainage water sampling sites in Kafr El-Sheikh Governorate. The photo-Fenton like reagent and photo zinc oxide combined with hydrogen peroxide showed much promise in the complete degradation and detoxification of lindane in contaminated drainage water. Effective microorganisms' formulation is promising as effective and safe bioremediation technique for lindane removal in drainage water.

\section{ACKNOWLEDGEMENT}

The authors thanks the financial supports providing from University of Kafrelsheikh, sector of postgraduate and research affairs, University research fund (Project No. KFUR03) in 2010.

\section{LITRATURE CITED}

1. Tomkins, B.A., Merriweather, R., Jenkins, R.A. \& Bayne, C.K. (1992). J. Assoc. Off. Anal. Chem. Int. 75, 1091-1099.

2. Colborn, T., Dumanoski, D. \&Myers, J.P. (1996). Our Stolen Future. Dutton, NY, SA.

3. Li, J., Zhang, G., Guo, L.L., Xu, W.H., Li, X., Dlee, C.S.L., Ding, A.J. \& Wanf, T. (2007). Organochlorine pesticides in the atmosphere o Guangzhou and Hong Kong: regional sources and long-range atmospheric transport. Atmospheric Environ. 41, 3889-3903. DOI: 10.1016/j.atmosenv.2006.12.052.

4. Benitez, F.J., Acero, J.L. \& Real, F.J. (2002). Degradation of carbofuran by using ozone, UV radiation and advanced oxidation processes. J. Hazard. Mat. 89, 51-65.

5. Derbalah, A.S., Nakatani, N. \& Sakugawa, H. (2004). Photocatalytic removal of fenitrothion in pure and natural waters by photo-Fenton reaction. Chemosphere 57, 635-644. DOI: $10.1016 / j$.

6. Evgenidou, E., Konstantinou, I., Fytianos, K. \& Poulios, I. (2007). Oxidation of tow organophosphorus insecticides by the photo-assisted Fenton reaction. Wat. Res. 41, 2015-2027. DOI: 10.1016/j.watres.2007.01.027.

7. Derbalah, A.S. (2009). Chemical remediation of carbofuran insecticide in aquatic system by advanced oxidation processes. J. Agric. Res. Kafr Elsheikh Univ. 35 (1), 308-327.

8. Derbalah, A.S.H. \& Belal, E.B. (2008). Biodegradation kinetics of cymoxanil in Aquatic system. Chem. Ecol. 3, 169-180. DOI: $10.1080 / 02757540802032173$.

9. Sangakkara, U.R. (2002). The Technology of Effective Microorganisms-Case Studies of Application' Royal Agricultural College, Cirencester, UK Research.

10. EM Technology (1998). Effective Microorganisms for a Sustainable Agriculture and Environment. From Link http:// emtech.org/prod01.htmm

11. Xu, X., Yang, H., Li, O.,Yang, B., Frank, X.W. \& Lee, S.C. (2007). Residues of organochlorine pesticides in near shore waters of Lai Zhou Bay and Jiao Zhou Bay, Shandong Peninsula, China. Chemosphere 68, 126-139. DOI: 10.1016/j. chemosphere.2006.12.021.

12. Papadakis, E.N., Vryzas, Z. \& Papadopoulou-Mourkidou, E. (2006). Rapid method for the determination of 16 organochlorine pesticides in sesame seeds by microwave-assisted extraction and analysis of extracts by gas chromatography-mass spectrometry. J. Chromat. A, 1127, 6-11.

13. Ezemonye, L.I., Ikpesu, T.O. \& Tongo, I. (2008). Distribution of lindane in water, sediment, and fish from the Warri river of the Niger delta, Nigeria. Arh. High Rad. Toksikol. 59, 261-270. DOI: 10.2478/10004-1254-59-2008-1906.

14. Abdel Megeed, A.A. \& Elnakeeb, A. (2008). Bioremediation of dimethoate by effective microorganisms in contaminated water. Terrestrial Aquat. Environ. Toxicol. 2, 1-4.

15. Derbalah, A.S., Massoud, A.H. \& Belal, E.B. (2008). Biodegrability of famoxadone by various microbial isolates in aquatic system. Land Contamination \& Reclama 16 (1), 13-23. DOI: 10.2462/09670513.876. 
16. Bancroft, J.D. \& Stevens, A. (1996). Theory and Practiceof Histological Techniques. (4th ed.). Churchill Livingstone. Edinburg, London, Melbourne and New York.

17. Abd-Allah, S.W. \& Hesham, M.G. (2003). Monitoring of pesticide residues in different sources of drinking water in some rural areas. Alex. J. Agric. Res. 48 (3), 187-199.

18. Ashry, M.A., Bayoumi, O.C., El-Fakharany, I.I., Derbalah, A.S. \& Ismail, A.A. (2006). Monitoring and removal of pesticidesresidues in drinking water collected from Kafr El-Sheikhgovernorate, Egypt. J. Agric. Res. Tanta Univ. 32 (3), 691-704

19. El-Sebae, A.H., Abou-Zeid, M.M. \& Saleh, M.A. (1993). Status and environmental impact of toxaphene in the Third World a case study of African agriculture. Chemosphere 27, 2063-2072.

20. Barakat, A.O. (2003). Persistent organic pollutants in smoke particles emitted during open burning of municipal solid wastes. Bull. Environ. Contamin. Toxicol. 70, 174-181. DOI: 10.1007/s00128-002-0172-9.

21. He, F., Zhao, D., Liu, J. \& Roberts, C.B. (2007). Stabilization of $\mathrm{Fe}-\mathrm{Pd}$ nanoparticles with sodium carboxymethyl cellulose for enhanced transport and dechlorination of trichloroethylene in soil and groundwater. Indian Engineer. Chem. Res. 46, 29-34. DOI: 10.1021/ie0610896.

22. He, F. \& Zhao, D. (2005). Preparation and characteriza-for degradation of chlorinated hydrocarbons in water. Environ. Sci. Technol. 39, 3314-3320. DOI:10.1021/es048743y.

23. Catastini, C., Sarakha, M., Mailhot, G. \& Bolte, M. (2002). Iron (III) Aquacomplesxes as effective photocatalysis for the degradation of pesticides in homogenous aqueous solutions. Sci. Tot. Environ. 298, 219-228.

24. El-Morsi, T.M., Emara, M.M., Abd El Bary, H.M.H., Abd-El-Aziz, A. \& Friesen K.J. (2002). Homogeneous degradation of $1,2<10$ tetrachlorodecane in aqueous solutions using hydrogen peroxide, iron and UV light. Chemosphere 47, 343-348. DOI: 10.1016/S0045-6535(01)00305-8.

25. Wang, Q. \& Lemely, A.T. (2002). Oxidation of diazinon by anodic Fenton treatment. Wat. Res. 36, 3237-3244. DOI: 10.1016/S0043-1354(02)00041-6.

26. Pare, B.P., Singh, S. \& Jonnalagadda, B. (2008). Visible light induced heterogeneous advanced oxidation process to degrade pararosanilin dye in aqueous suspension of $\mathrm{ZnO}$. Indian J. Chem. 4, 830-835.

27. Wang, H., Xie, C., Zhang, W., Cai, Z., Cai, S., Yang, Z. \& Gui, Y. (2007). Comparison of dye degradation efficiency using $\mathrm{ZnO}$ powders with various size scales. J. Hazard. Mat.141, 645-652. DOI: org/10.1016/j.jhazmat.2006.07.021.

28. Valdés-Solís, T.P., Valle-Vigón, P., Álvarez, S., Marbán, G. \& Fuertes, A.B. (2007 a). Encapsulation of nanosized catalysts in the hollow core of a mesoporous carbon capsule. J. Catal. 251, 239-243. DOI: 10.1016/j.jcat.2007.07.006.

29. Valdés-Solís, T.P., Valle-Vigón, P., Álvarez, S., Marbán, G. \& Fuertes, A.B. (2007 b). Manganese ferrite nanoparticles synthesized through a nanocasting route as a highly active Fenton catalyst. Catal. Commun. 8, 2037-2042. DOI: 10.1016/j. catcom.2007.03.030

32. Lines, M.G. (2008). Nanomaterials for practical functional uses. J. Alloys Compd. 449, 242-245. DOI: 10.1016/j.

30. Mamalis, A.G. (2007). Recent advances in nanotechnology. J. Mat. Process. Technol. 181, 52-58. DOI:org/10.1016/j. jmatprotec.2006.03.052.

31. Miyazaki, K. \& Islam, N. (2007). Nanotechnology systems of innovation - an analysis of industry and academia research activities. Technovation 27, 661-675. DOI: 10.1016/j. technovation.2007.05.009.

33. Yuan, G. \& Theng, B.K.G. (2008). Nanopaticles in the soil environment. Elements 4, 395-399. DOI:10.2113/gs

34. Bell, A.T. (2003). The impact of nanoscience on heterogeneous catalysis. Sci. 299, 1688-1691. DOI: 10.1126/ science. 1083671 .
35. Feng, J., Hu, X. \& Yue, P.L. (2004 a). Novel bentonite clay-based $\mathrm{Fe}$-nanocomposite as a heterogeneous catalyst for photo-Fenton discoloration and mineralization of Orange II. Environ. Sci. Technol. 38, 269-275. DOI: 10.1021/es034515c.

36. Feng, J., Hu, X. \& Yue, P.L. (2004 b). Discoloration and mineralization of Orange II using different heterogeneous catalysts containing Fe: a comparative study. Environ. Sci. Technol. 38, 5773-5778. DOI: 10.1021/es049811j.

37. Zelmanov, G., Semiat, R. (2008). Iron(3) oxide-based nanoparticles as catalysts in advanced organic aqueous oxidation. Wat. Res. 42, 492-498. DOI: 10.1016/j.watres.2007.07.045.

38. Nurmi, J., Tratnyek, P.G., Sarathy, V., Baer, D.R., Amonette, J.E., Pecher, K., Wang, C., Linehan, J.C., Matson, D.W., Penn, R.L. \& Driessen, M.D. (2005). Characterization and properties of metallic iron nanoparticle: spectroscopy, electrochemistry, and kinetics. Environ. Sci. Technol. 39, 1221-1230. DOI: 10.1021/es049190u.

39. Liu, W.T. (2006). Nanoparticles and their biological and environmental applications. J. Biosci. Bioeng. 102, 1-7. DOI: $10.1263 /$ jbb.102.1

40. Higa, T. (1995). What is EM Technology. College of Agriculture, University of Ryukyus, Okinawa, Japan.

41. EM Trading (2000). Effective Microorganisms (EM) from Sustainable Community Development. From EM Technology Product Link http://www.emtrading.com.html

42. Diver, S. (2001). Nature Farming and Effective Microorganisms',Rhizosphere II: Publications. from Steve Diver Link http://ncatark.uark.edu/ steved/Nature-Farm-EM.html

43. Quik, J.T.K., Velzeboer, I., Wouterse, M., Koelmans, A.A. \& Van de Meent, D. (2014). Heteroaggregation and Sedimentation Rates for Nanomaterials in Natural Waters. Wat. Res. 48, 269-279. DOI: 10.1016/j.watres.2013.09.036.

44. El-Safty, S.A., Hoa, N.D. \& Shenashen M.A. (2012). Topical Developments of Nanoporous Membrane Filters for Ultrafine Noble Metal Nanoparticles. Eur. J. Inorg. Chem. 5439-5450. DOI: 10.1002/ejic.201200629. 